\title{
Osmopriming, antioxidative action, and thermal stress in sunflower seeds with different vigor levels
}

\section{Condicionamento osmótico, ação antioxidativa e estresse térmico em sementes de girassol com diferentes níveis de vigor}

Tiago Teixeira Viana Barros ${ }^{1}$; Daniel Teixeira Pinheiro ${ }^{2 *}$; Guilherme Fontes Valory Gama3; Denise Cunha Fernandes dos Santos Dias'; Laércio Junio da Silva ${ }^{4}$

\section{Highlights}

The effects of seed osmopriming are important under extremal temperatures.

Osmopriming improved the performance of sunflower seeds under thermal stress.

Osmopriming improved the antioxidant action of sunflower seeds under thermal stress.

\begin{abstract}
The osmopriming technique can reduce the period between sowing and the emergence of seedlings in the field, as well as favor seed performance under stress conditions. This study aimed to evaluate the effect of osmopriming on the physiological performance and antioxidative enzymatic activity of sunflower seeds with different vigor levels and exposed to thermal stress. Three sunflower seed lots of the cultivar Hélio 250 were used. Initially, the seeds were evaluated by germination and vigor tests to characterize the lots. Subsequently, they were primed in a polyethylene glycol 6000 solution at $-2.0 \mathrm{MPa}$ and $15{ }^{\circ} \mathrm{C}$ for $8 \mathrm{~h}$. Then, the primed and unprimed seeds were tested for physiological quality (germination, first germination count, percentage and emergence speed index of seedlings, and seedling dry matter) and determination of the activity of the enzymes superoxide dismutase (SOD), catalase (CAT), ascorbate peroxidase (APX), and peroxidase (POX) under three temperatures: $15^{\circ} \mathrm{C}$ (sub-optimal), $25^{\circ} \mathrm{C}$ (optimal), and $35^{\circ} \mathrm{C}$ (supra-optimal). The physiological tests allowed classifying lots 1, 2, and 3 into three different vigor levels, i.e., high, medium, and low, respectively. Osmopriming favored the performance of sunflower seeds in terms of germination and vigor at all the analyzed temperatures. This effect was more pronounced in lots of lower physiological quality at sub-optimal and supra-optimal temperatures. Sub-and supra-optimal temperatures led to a reduction in the physiological performance of seeds, mainly in less vigorous lots. In general, osmopriming favored an

${ }^{1}$ M.Sc. in Crop Science, Federal University of Viçosa, Agronomy Department, UFV, Viçosa, MG, Brazil. E-mail: tiago. barros.agronomia@gmail.com

2 PhD. in Crop Science, Agronomy Department, UFV, Viçosa, MG, Brazil. E-mail: pinheiroagroufv@gmail.com

${ }^{3}$ PhD. Student in Crop Science, Agronomy Department, UFV, Viçosa, MG, Brazil. E-mail: guilhermefontes.gama@ gmail.com

${ }^{4}$ Profs. of Agronomy Department, UFV, Viçosa, MG, Brasil. E-mail: dcdias@ufv.br; laercio.silva@ufv.br

* Author for correspondence
\end{abstract}

Received: July 06, 2020 - Approved: Dec. 03, 2020 
increase in the activity of the enzymes SOD, CAT, POX, and APX, mainly in low vigor seeds exposed to sub and supra-optimal temperatures. Osmopriming of sunflower seeds in PEG 6000 at $-2.0 \mathrm{MPa}$ for 8 hours is efficient to improve the performance of less vigorous lots under stress due to the sub-and supra-optimal temperatures, favoring an increase in the activity of enzymes of the antioxidative system.

Key words: Abiotic stress. Oxidative stress. Helianthus annuus L. Temperature. Seed vigor.

\section{Resumo}

A técnica de condicionamento osmótico reduz o período entre a semeadura e a emergência de mudas no campo, além de favorecer o desempenho das sementes em condições de estresse. O objetivo do estudo foi avaliar o efeito do condicionamento osmótico no desempenho fisiológico e na atividade enzimática antioxidativa de sementes de girassol com diferentes níveis de vigor e expostas ao estresse térmico. Foram utilizados três lotes de sementes de girassol, cultivar Hélio 250. Inicialmente, as sementes foram avaliadas pelos testes de germinação e vigor para caracterizar os lotes. Em seguida, foram condicionadas em solução de polietilenoglicol 6000 a -2,0 MPa, a $15^{\circ} \mathrm{C}$ por $8 \mathrm{~h}$. Posteriormente, as sementes condicionadas e não condicionadas foram testadas quanto à qualidade fisiológica (germinação, contagem de primeira germinação, porcentagem e índice de velocidade de emergência das plântulas e matéria seca das plântulas) e determinação da atividade das enzimas superóxido dismutase (SOD), catalase (CAT), ascorbato peroxidase (APX) e peroxidase (POX) sob três temperaturas: $15^{\circ} \mathrm{C}$ (sub ótima), $25^{\circ} \mathrm{C}$ (ótima) e $35^{\circ} \mathrm{C}$ (supra ótima). Através de testes fisiológicos, os lotes 1, 2 e 3 foram classificados em três níveis diferentes de vigor, sendo alto, médio e baixo, respectivamente. O condicionamento osmótico favoreceu o desempenho das sementes de girassol na germinação e vigor em todas as temperaturas analisadas. Este efeito foi mais pronunciado em lotes de qualidade fisiológica mais baixa em temperaturas sub ótima e supra ótima. As temperaturas sub e supra ótimas causaram uma redução no desempenho fisiológico das sementes, principalmente nos lotes menos vigorosos. Em geral, o condicionamento osmótico favoreceu um aumento na atividade das enzimas SOD, CAT, POX e APX, principalmente em sementes de baixo vigor expostas às temperaturas sub e supra ótimas. O condicionamento osmótico de sementes de girassol no PEG 6000 a -2,0 MPa, por 8 horas, é eficiente para melhorar o desempenho dos lotes com menos vigor sob estresse devido às temperaturas sub e supra ótimas, favorecendo o aumento da atividade das enzimas do sistema antioxidativo.

Palavras-chave: Estresse abiótico. Estresse oxidativo. Helianthus annuus L. Temperatura. Vigor de sementes.

\section{Introduction}

Sunflower (Helianthus annuus L.) is an important crop worldwide due to the high oil content in its seeds, in addition to its nutritional and ornamental value (Seiler, Qi, \& Marek, 2017). Thus, seeds as primary inputs are essential for obtaining uniform stands and high yield. The irregular maturation of seeds (Rondanini, Savin, \& Hall, 2007), contamination by microorganisms (Kononenko, Ustyuzhanina, \& Burkin, 2018), and postharvest dormancy (De Bont et al., 2019) are factors that interfere with the physiological potential of seeds, affecting the initial development of seedlings in the field (Finch-Savage \& Bassel, 2016).

In Brazil, sunflower cultivation is mainly concentrated in the Cerrado region during the off-season of soybean and corn 
but encompasses most Brazilian states, with different edaphoclimatic conditions. Thus, the seeds are subject to variations in the temperature conditions at sowing and they can present different physiological and biochemical responses depending on their physiological potential. Sunflower is sensitive to extreme temperatures (high and low), which cause a reduction in the rate and percentage of emergence, seedling growth, disease occurrence, and others (Akladious, 2014; Henning, Ceronio, \& Nel, 2017; Górnik \& Lahuta, 2017).

Seeds become susceptible to theaction of oxidative stress when exposed to stressful situations, such as sub- and supra-optimal temperatures, which consists of the imbalance between the production of reactive species (ROS) and the enzymatic and non-enzymatic antioxidative mechanisms (Noctor, Reichheld, \& Foyer, 2018). The action of antioxidative enzymes such as superoxide dismutase (SOD) catalase (CAT), ascorbate peroxidase (APX), and peroxidase (POX) play a fundamental role in eliminating excess ROS, mitigating their harmful effects on seeds (Kumar, Prasad, Banerjee, \& Thammineni, 2015).

The use of treatments that favor a rapid and uniform establishment of sunflower in the field are determinant for its yield due to the characteristics of the seeds and the range of environmental conditions to which the crop is subject. In this context, osmopriming can be considered a promising technique, as it stimulates the initial metabolic processes of germination, increases the activity of the antioxidant system and the repair of membranes, and enhances higher germination and emergence under adverse conditions (Ibrahim, 2016). This technique consists of subjecting the seeds to controlled hydration, sufficient to promote the pre-germinative metabolic activities but without allowing root protrusion (Jisha, Vijayakumari, \& Puthur, 2013).

Osmopriming provides a rapid and uniform emergence and increases resistance to unfavorable conditions (Paparella et al., 2015; Balabusta, Szafrańska, \& Posmyk, 2016). It is a technique most commonly used in seeds of ornamental and vegetable species, but it has also shown promising results in rice (Hussain, Khan, Hussain, \& Nie, 2016), soybean (Dai, Zhu, Yin, Du, \& Zhang, 2017), sunflower (Singh, Singh, \& Singh, 2015), and others. Bailly, Benamar, Corbineau and Côme (2000) reported a significant increase in sunflower seed germination after osmopriming with polyethylene glycol (PEG) 6000 at -2.0 MPa, highlighting an increase in the activity of antioxidative enzymes such as SOD and CAT. However, the effects of osmopriming may vary depending on the physiological potential of seeds and these studies have not considered this factor.

Thus, this study aimed to evaluate the effect of osmopriming on the physiological performance and antioxidative enzymatic activity of sunflower seeds with varying vigor levels and subjected to thermal stress.

\section{Materials and Methods}

The study was conducted at the Laboratory of Seed Research of the Department of Agronomy at the Universidade Federal de Viçosa, Viçosa, MG, Brazil. Seeds from three sunflower lots of the cultivar Hélio 250 (HELIAGRO) with different vigor levels were used. 
An initial characterization of the lots was carried out based on the following tests:

Moisture content: The test was carried out by the oven method at $105 \pm 3$ ${ }^{\circ} \mathrm{C}$ for 24 hours (Ministério da Agricultura, Pecuária e Abastecimento [MAPA], 2009). Four replications of 25 seeds were used and the results were expressed as a percentage (wet basis).

Germination: four replications of 50 seeds were sown on Germitest ${ }^{\circledR}$ paper moistened with water in a volume equivalent to 2.5 times the dry paper weight. Rolls were made and placed in a germinator at $25^{\circ} \mathrm{C}$. The counts of the number of normal seedlings were performed at 10 days after sowing. The results were expressed as a percentage of normal seedlings (MAPA, 2009).

First germination count: the test was carried out together with the germination test and consisted of the percentage of normal seedlings obtained on the fourth day after sowing (MAPA, 2009).

Seedling emergence: the test was carried out in a growth chamber at $25{ }^{\circ} \mathrm{C}$ in trays filled with sand moistened to $60 \%$ of the retention capacity. Four replications of 50 seeds per lot were sown at a depth of 1.0 $\mathrm{cm}$. Daily counts were performed until the stand stabilized. The results were expressed as a percentage of seedlings with cotyledons above the substrate level.

Emergence speed index (ESI): the index was calculated using the data obtained from the daily counts performed in the emergence test, as proposed by Maguire (1962).

Accelerated aging: the test was conducted using four replications of 50 seeds placed on a screen coupled in transparent plastic boxes $(11 \times 11 \times 3.5 \mathrm{~cm})$ with $40 \mathrm{~mL}$ of water and maintained in an oven at $41^{\circ} \mathrm{C}$ for 48 hours. Subsequently, the seeds were submitted to the germination test, according to the previously described methodology, and the evaluation was carried out on the fourth day.

After characterizing the initial quality, the seeds of each lot were primed in aerated polyethylene glycol 6000 (PEG 6000) solution with an osmotic potential adjusted to -2.0 MPa (400 g L-1) (Michel \& Kaufmann, 1973) at $15^{\circ} \mathrm{C}$ for eight hours (Chojnowski, Corbineau, \& Côme, 1997). The seeds were placed in Erlenmeyer flasks with $350 \mathrm{~mL}$ of the osmotic solution, sealed with a rubber septum, and supplied with constant aeration using an air pump. At the end of the osmopriming, the seeds were removed, washed in running water, and dried under laboratory conditions $(25 \pm 3$ ${ }^{\circ} \mathrm{C}$ and $60 \% \mathrm{RH}$ ) until reaching an initial water content of approximately $10 \%$. Unprimed seeds were used as control.

Then, the seeds of each lot were evaluated for physiological potential and activity of the antioxidative enzyme system under three constant temperature levels: $15^{\circ} \mathrm{C}$ (sub-optimal), $25^{\circ} \mathrm{C}$ (optimal), and $35^{\circ} \mathrm{C}$ (supraoptimal), as described below.

Germination under different temperatures: this test was carried out according to the previously described methodology, using temperatures of 15,25 , and $35^{\circ} \mathrm{C}$. The results were expressed as a percentage of normal seedlings.

First germination count at different temperatures: this test was carried out together with the germination test, using temperatures of 15,25 , and $35^{\circ} \mathrm{C}$. 
Seedling dry matter: after the germination evaluation (tenth day), the seedlings were packed in paper bags and dried in a forced-air oven at $72{ }^{\circ} \mathrm{C}$ until reaching constant weight. Subsequently, the samples were weighed on a precision scale and the results were expressed in g seedling ${ }^{-1}$.

Seedling emergence at different temperatures: it was conducted as described for the emergency test, in germinators at temperatures of 15,25 , and $35^{\circ} \mathrm{C}$.

Emergence speed index (ESI) at different temperatures: this test was carried out together with the emergence test through daily counts of emerged normal seedlings and calculated according to Maguire (1962).

Determination of enzyme activity in the antioxidative system: initially, about 50 seeds from each lot and treatment (primed or not) were weighed (initial weight) and arranged to soak on paper towels moistened with water and maintained at temperatures of 15,25 , and $35^{\circ} \mathrm{C}$, aiming at defining the time necessary to reach the stage II of soaking (Bewley, Bradford, \& Hilhorst, 2013) and reaching sufficient moisture content to activate the enzymatic activity (about 35\%). For this, successive seed weighings were performed at regular intervals of time until the required weight (RW), corresponding to $35 \%$ moisture, was obtained. Equation (1) was used:

$$
\mathrm{RW}=\left(100-\frac{M C i}{100}-M C d\right) x W i
$$

where RW is the required weight at the desired moisture content $(\mathrm{g}), \mathrm{MCi}$ is the initial moisture content (\%), MCd is the desired moisture content (\%), and Wi is the initial seed weight (g).

These results allowed defining the average soaking time of seeds at sub-optimal $\left(15^{\circ} \mathrm{C}\right)$, optimal $\left(25^{\circ} \mathrm{C}\right)$, and supra-optimal temperatures $\left(35^{\circ} \mathrm{C}\right)$ as 48,24 , and $12 \mathrm{~h}$, respectively. The seeds were soaked in paper towel rolls at the corresponding temperatures and times. The activity of the enzymes superoxide dismutase (SOD), catalase (CAT), ascorbate peroxidase (APX), and peroxidase (POX) were determined using crude extracts obtained through the maceration of $0.3 \mathrm{~g}$ of embryos (cotyledons and embryonic axis taken by removing the integument) in liquid nitrogen, followed by the addition of $2 \mathrm{~mL}$ of extraction medium, potassium phosphate buffer $(0.1 \mathrm{M}$, $\mathrm{pH} 6.8)$, ethylenediaminetetraacetic acid (EDTA) (0.1 mM), phenylmethylsulfonyl fluoride (PMSF) (1.0 mM), and $1 \%(w / v)$ polyvinylpolypyrrolidone (PVPP) (Peixoto, Cambraia, Sant'Anna, Mosquim, \& Moreira, 1999). The solution was centrifuged (homogenized) at 19,000 $\mathrm{g}$ for 15 min at $4{ }^{\circ} \mathrm{C}$ to obtain the enzyme extract.

Superoxide dismutase (SOD) activity was determined by adding the enzyme extract to $50 \mathrm{mM}$ sodium phosphate buffer ( $\mathrm{pH} 7.8), 13$ mM methionine, $75 \mu \mathrm{M}$ p-nitro blue tetrazolium (NBT), $0.1 \mathrm{mM}$ EDTA, and $2 \mu \mathrm{M}$ riboflavin (Del Longo, González, Pastori, \& Trippi, 1993). The NBT photoreduction was performed according to Giannopolitis and Ries (1977). A unit of SOD was defined as the amount of enzyme required to inhibit NBT photoreduction by $50 \%$ (Beauchamp \& Fridovich, 1971). The result was expressed in $\mathrm{U} \mathrm{min}^{-1} \mathrm{mg}^{-1}$ protein.

Catalase activity (CAT) was determined by adding the enzyme extract to $50 \mathrm{mM}$ potassium phosphate buffer $(\mathrm{pH} 7.0)$ and 12.5 mM H2O2 (Havir \& McHale, 1987). The enzyme activity was calculated using the molar extinction coefficient of $36 \mathrm{M}^{-1} \mathrm{~cm}^{-1}$ (Anderson, Prasad, \& Stewart, 1995), and the result was expressed in $\mu \mathrm{mol} \mathrm{min}^{-1} \mathrm{mg}^{-1}$ protein. 
Ascorbate peroxidase (APX) activity was determined by adding $100 \mu \mathrm{L}$ of the enzyme extract to $50 \mathrm{mM}$ potassium phosphate buffer (pH 7.8), $0.5 \mathrm{mM}$ ascorbic acid, $0.1 \mathrm{mM}$ EDTA, and $1.2 \mathrm{mM} \mathrm{H}_{2} \mathrm{O}_{2}$. The enzyme activity was calculated using the molar extinction coefficient of $2.8 \mathrm{mM}^{-1} \mathrm{~cm}^{-1}$ (Nakano \& Asada, 1981), and the result was expressed in nmol $\mathrm{min}^{-1} \mathrm{mg}^{-1}$ protein.

Peroxidase (POX) activity was determined by adding the enzyme extract to $25 \mathrm{mM}$ potassium phosphate buffer (pH 6.8), 20 mM pyrogallol, and $20 \mathrm{mM} \mathrm{H}_{2} \mathrm{O}_{2}$ (Kar \& Mishra, 1976). The enzyme activity was calculated using the molar extinction coefficient of $2.47 \mathrm{M}^{-1} \mathrm{~cm}^{-1}$ (Chance \& Maehly, 1955), and the result expressed was in $\mu \mathrm{mol} \mathrm{min}^{-1} \mathrm{mg}^{-1}$ protein.

Total protein content: it was determined with the same extract used in the enzyme evaluations, using bovine serum albumin (BSA) as a standard (Bradford, 1976). An aliquot of $100 \mu \mathrm{L}$ of the enzyme extract was added to 1 $\mathrm{mL}$ of Bradford reagent, followed by stirring. After 20 minutes, the sample absorbance was read on a spectrophotometer at $595 \mathrm{~nm}$.
Experimental design and statistical analysis: The experiment was carried out in a completely randomized design in a 2 (primed or unprimed seeds) $\times 3$ (temperatures of 15,25 , and $35{ }^{\circ} \mathrm{C}$ ) factorial scheme for each lot. The data were subjected to analysis of variance and the means were compared by the Tukey test at a $5 \%$ probability after confirming the normal distribution of errors by the Shapiro-Wilk test. A multivariate principal component analysis (PCA) and Pearson linear correlation analysis (r) were also performed for all combinations between the analyzed variables. The software R (R Core Team [R], 2018) was used.

\section{Results and Discussion}

The initial characterization showed the stratification of lots into three levels of physiological quality, with better performance of Lot 1 and worse performance of Lot 3, with Lot 2 in an intermediate position (Table 1). Lot 3 was the only lot that did not show the minimum germination value of $75 \%$ established for the commercialization of sunflower seeds in Brazil (MAPA, 2013). Thus, the lots were classified as high (Lot 1), medium, (Lot 2), and low vigor (Lot 3).

Table 1

Initial characterization of the physiological quality of three lots of sunflower seeds

\begin{tabular}{|cccccc|}
\hline Lot & G (\%) & FGC (\%) & EMERG (\%) & ESI & AA (\%) \\
\hline 1 & $92 \mathrm{a}$ & $83 \mathrm{a}$ & $89 \mathrm{a}$ & $10.5 \mathrm{a}$ & $80 \mathrm{a}$ \\
\hline 2 & $76 \mathrm{~b}$ & $73 \mathrm{~b}$ & $75 \mathrm{~b}$ & $9.6 \mathrm{~b}$ & $65 \mathrm{~b}$ \\
\hline 3 & $71 \mathrm{c}$ & $46 \mathrm{c}$ & $70 \mathrm{c}$ & $9.1 \mathrm{~b}$ & $59 \mathrm{c}$ \\
\hline $\mathrm{CV}(\%)$ & 2.18 & 3.35 & 2.20 & 3.58 & 2.32 \\
\hline $\mathrm{F}_{0.05}$ & 7.340 & 6.142 & 7.819 & 19.421 & 14.789 \\
\hline
\end{tabular}

G - Percentage of germination, FGC - First germination count, EMERG - Percentage of emergence, ESI - Emergence speed index, AA - Accelerated aging. Means followed by the same letter do not differ by Tukey's test $(p<0.05)$. 
All the analyzed variables and lots showed a significant effect for the interaction between osmopriming and temperature factors. Osmopriming at all tested temperatures provided no significant differences between seed germination in Lots 1 (high vigor) and 2 (medium vigor) compared to unprimed seeds. Otherwise, osmopriming favored seed germination of the lot with the lowest physiological quality (Lot 3) at all analyzed temperatures. This effect was more pronounced at the supra-optimal temperature $\left(35^{\circ} \mathrm{C}\right)$, with an average increase of $35 \%$ (18 percentage points) in germination. Lot 3 (low vigor), initially with $71 \%$ germination at the optimal temperature $\left(25^{\circ} \mathrm{C}\right)$, reached $79 \%$ after osmopriming, a value higher than the minimum germination standard established for the commercialization of sunflower seeds (75\%) (Table 2) (MAPA, 2013).

Considering the other tests, the osmoprimed seeds of Lot 2 (medium vigor) presented higher averages of first germination count (FGC), seedling dry matter (SDM), and ESI than unprimed seeds, regardless of the analyzed temperature (Table 2). On the other hand, osmopriming in Lot 3 (low vigor) provided higher averages of germination, first count, ESI, and emergence than unprimed seeds. Only the variable SDM in Lot 1 (high vigor) showed the superiority of osmoprimed seeds compared to unprimed seeds, regardless of the temperature.

In general, the most evident effects of osmopriming were observed in the seeds of medium (Lot 2) and low vigor lots (Lot 3) at temperatures of 15 and $35^{\circ} \mathrm{C}$. These results show the recovery of the physiological performance of osmoprimed seeds under stress conditions (Araújo et al., 2016). In this sense, the results observed at a temperature of $15^{\circ} \mathrm{C}$ reinforce that this technique can improve the performance of sunflower seeds under low temperatures (Hewezi, Léger, El Kayal, \& Gentzbittel, 2006). This better performance of osmoprimed seeds is related to factors such as the brief and transient activation of the pre-germinative metabolism, with antioxidant functions and promotion of DNA repair events (Paparella et al., 2015). Finch-Savage and Bassel (2016) question whether osmopriming can improve vigor or whether the seed germination stage only advances. However, the authors reinforce that seeds subjected to these techniques are metabolically advanced and express the germination process more quickly and uniformly, in addition to remaining tolerant to desiccation.

Regarding the effects of different temperatures, a higher physiological performance of the seeds of the three analyzed lots was observed at a temperature of $25^{\circ} \mathrm{C}$. Overall, osmoprimed and unprimed seeds of Lot 1 (high vigor) were less sensitive to thermal stress, with reductions in germination speed and seedling development when submitted to a temperature of $15^{\circ} \mathrm{C}$. Seeds of Lots 2 (medium vigor) and 3 (low vigor) showed significant reductions in germination and vigor when unprimed and submitted to temperatures of 15 and $35^{\circ} \mathrm{C}$ (Table 2). 
Table 2

Average values obtained from the germination (G), first germination count (FGC), seedling dry matter (SDM), emergence speed index (ESI), and emergence (EMERG) tests of three lots of unprimed (UNP) and osmoprimed (OP) sunflower seeds (L1, L2, and L3) submitted to different temperatures

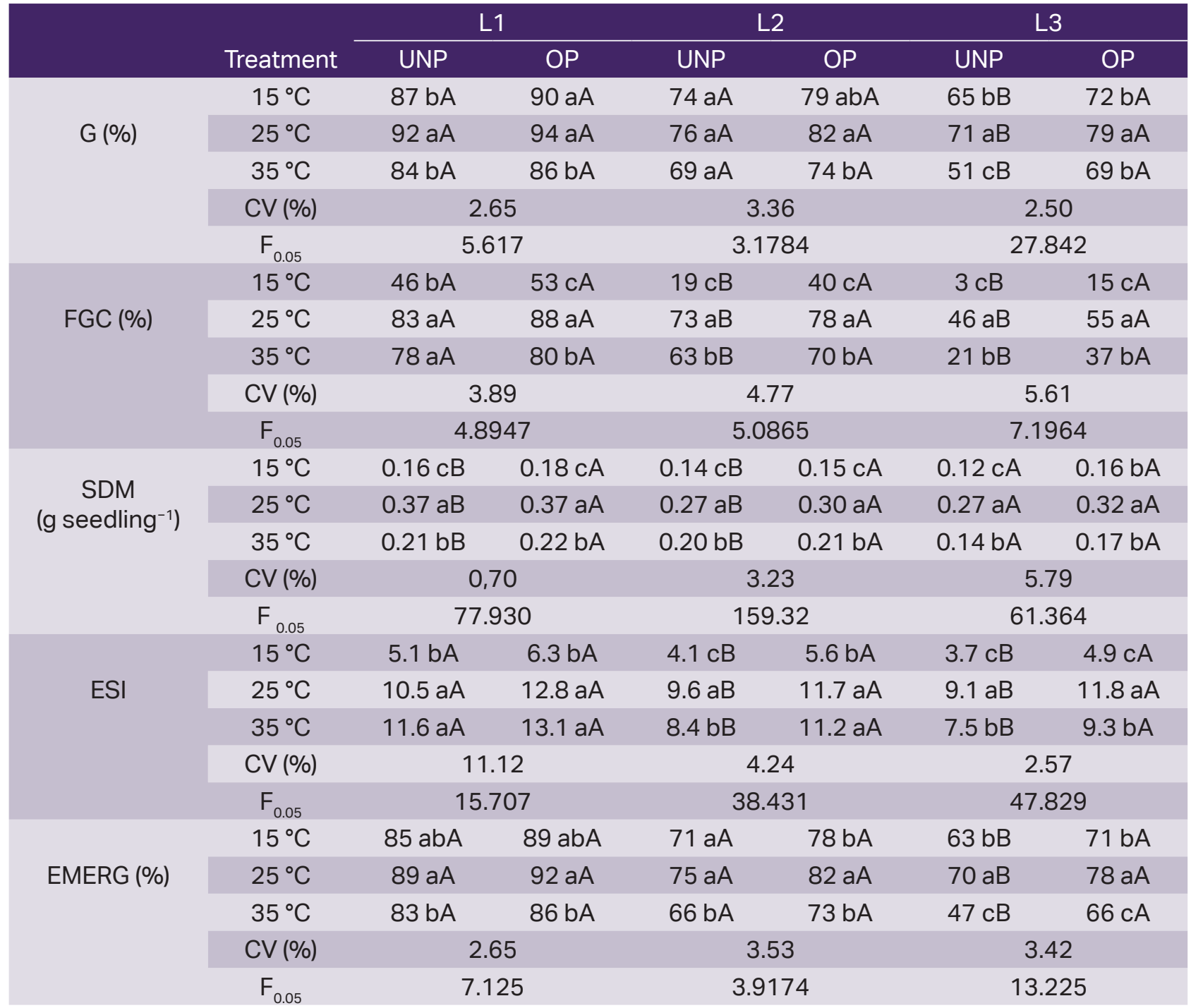

G - Germination, FGC - First germination count, SDM - Seedling dry matter, ESI - Emergence speed index, EMERG Emergence. Means followed by the same lowercase letters in the column (temperatures) and uppercase letters in the row (osmopriming) within each lot do not differ from each other by the Tukey test $(p<0.05)$. 
Temperatures of 15 and $35^{\circ} \mathrm{C}$ caused a reduction in the physiological performance of seeds, mainly of medium and low vigor lots (Lots 2 and 3). Several physiological changes occur in seeds submitted to low temperatures, such as hormonal imbalance, less metabolic activity, less degradation and transport of reserves to the embryo, and other factors that contribute to reducing germination and vigor (Wang et al., 2018). Also, another effect related to the damage caused by low temperatures in germination is the potentiation of oxidative stress through ROS accumulation (Pál, Gondor, \& Janda, 2013). The prolonged exposure of sunflower seedlings to low temperatures is also responsible for generating cooling lesions, which directly reflects the reduction of the emergence speed and root growth (Górnik, Badowiec, \& Weidner, 2014). Thus, this set of factors may have influenced the reduction in the performance of sunflower seeds submitted to a temperature of $15^{\circ} \mathrm{C}$ compared to $25^{\circ} \mathrm{C}$. Considering the low performance of seeds submitted to the temperature of $35^{\circ} \mathrm{C}$ relative to $25^{\circ} \mathrm{C}$, these effects are probably related to an increase of the respiratory rates and higher ROS production, which can cause mainly physiological damages such as protein denaturation, enzymatic inhibition, lipid peroxidation, and damage to nucleic acids (Gill \& Tuteja, 2010; Balabusta et al., 2016; Mittler, 2017).

In summary, the results observed in the physiological analyses confirm that low vigor seeds are more demanding at ideal temperatures to express their best physiological performance. Also, osmopriming assists in attenuating stress under sub-optimal and supra-optimal temperatures.

No significant effect of osmopriming was observed on the activity of the enzyme superoxide dismutase (SOD) in seeds of Lots 1 (high vigor) and 2 (medium vigor). The temperature in Lot 1 (high vigor) also did not change the activity of this enzyme, both in osmoprimed and unprimed seeds. The temperature of $15{ }^{\circ} \mathrm{C}$ in Lot 2 (medium vigor) provided lower activities of this enzyme in osmoprimed and unprimed seeds. Osmopriming in Lot 3 (low vigor) provided higher SOD activities at temperatures of 25 and $35^{\circ} \mathrm{C}$. The temperature of $35^{\circ} \mathrm{C}$ led to a reduction in SOD activity in this lot (Figure $1 \mathrm{~A}$ ). 

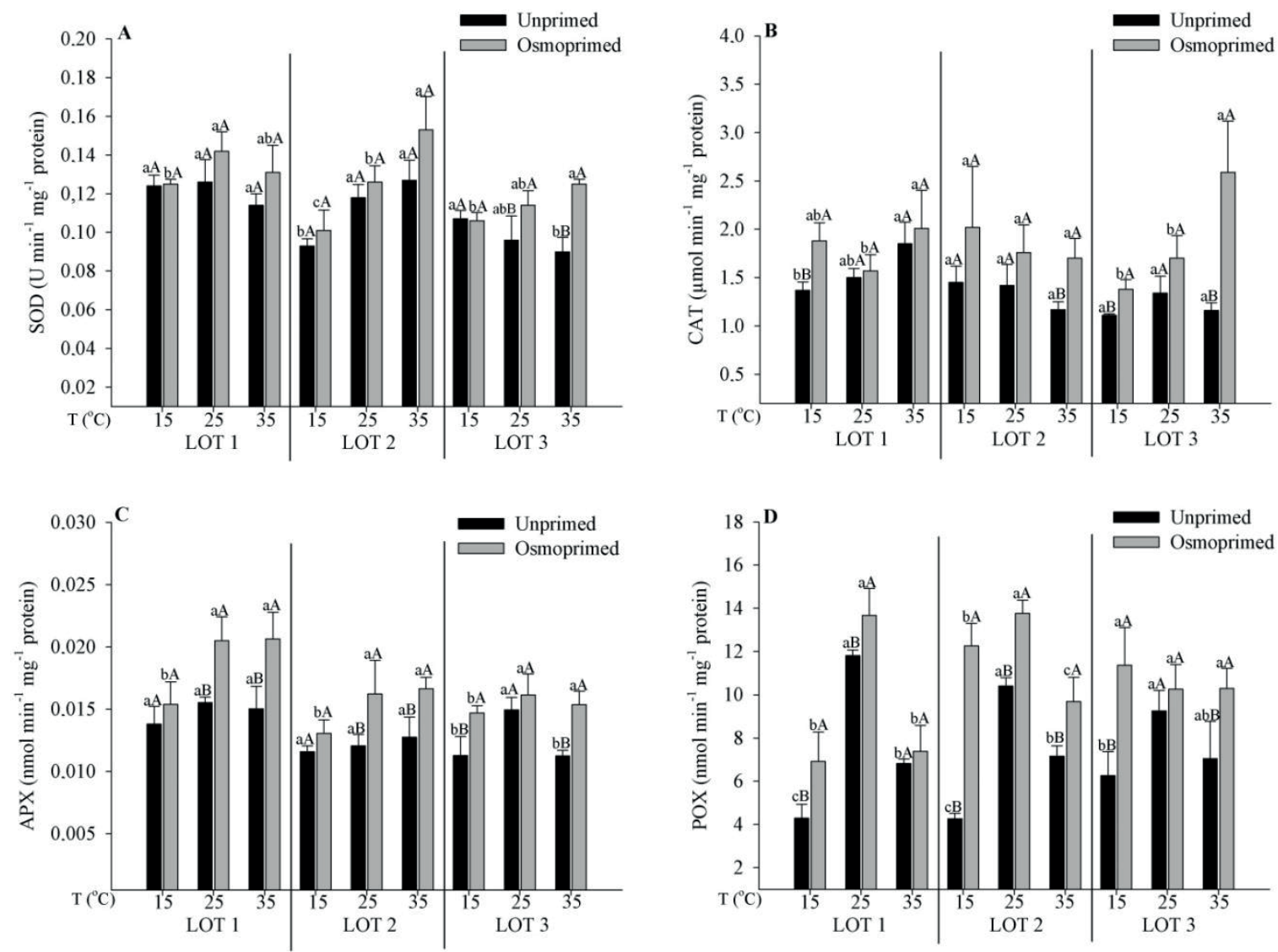

Figure 1. Activity of the antioxidative enzymes superoxide dismutase (A), catalase (B), ascorbate peroxidase (C), and peroxidase (D) in three lots of sunflower seeds submitted to different temperatures and osmopriming. Means followed by the same lowercase letters (temperature) and uppercase letters (osmopriming) do not differ from each other by the Tukey test $(P<0.05)$.

Superoxide dismutase is the first enzyme to act in the antioxidant system and is a key part of neutralizing oxidative stress since it transforms the superoxide radical $\left(\mathrm{O}_{2}^{--}\right)$into hydrogen peroxide $\left(\mathrm{H}_{2} \mathrm{O}_{2}\right)$, which is less reactive and reduced mainly by CAT and APX enzymes (Gill \& Tuteja, 2010; Das \& Roychoudhury, 2014). This effect can be observed in sunflower seeds of Lots 2 (medium vigor) and 3 (low vigor), in which osmopriming favored the physiological performance of seeds under temperatures of 15 and $35^{\circ} \mathrm{C}$ (Table 2). Similarly, osmoprimed maize seeds had a higher capacity for SOD activation, directly reflecting on better physiological performance (Ahmad et al., 2015).
Catalase (CAT) activity increased significantly with osmopriming, mainly in Lots 2 (medium vigor) and 3 (low vigor) at temperatures of 15 and $35^{\circ} \mathrm{C}$ (Figure 1B). The only difference found in Lot 1 (high vigor) was the lower activity of this enzyme in unprimed seeds at the temperature of $15^{\circ} \mathrm{C}$. Considering the temperatures, Lot 1 (high vigor) showed higher CAT activity at $35{ }^{\circ} \mathrm{C}$ regardless of the osmopriming. The temperature in Lot 2 (medium vigor) did not influence CAT activity, while the temperature of $35^{\circ} \mathrm{C}$ provided the higher activity of this enzyme in osmoprimed seeds of Lot 3 (low vigor). 
Catalase is an enzyme active mainly at high $\mathrm{H}_{2} \mathrm{O}_{2}$ concentrations, playing an important role in detoxification (Ye et al., 2012). Therefore, there is an indication that the temperatures of 15 and $35^{\circ} \mathrm{C}$ contributed significantly to $\mathrm{H}_{2} \mathrm{O}_{2}$ accumulation, especially in medium and low vigor lots (Figure 1B). The increase in CAT activity in osmoprimed sunflower seeds points to higher germination and seedling development levels (Bailly et al., 2000). Moreover, the enzymes SOD and CAT act together and integrated in the antioxidative mechanism, neutralizing, and maintaining toxic products at controlled levels (Mittler, 2017).

Osmopriming provided significant increases in the ascorbate peroxidase (APX) activity at different temperatures (Figure 1C). This increase in Lots 1 (high vigor) and 2 (medium vigor) was observed at temperatures of 25 and $35^{\circ} \mathrm{C}$. Otherwise, this increase in Lot 3 (low vigor) was observed at temperatures of 15 and $35^{\circ} \mathrm{C}$. No significant difference was observed in the effect of temperature on the APX activity in unprimed seeds in Lots 1 (high vigor) and 2 (medium vigor). The highest APX activity in Lot 3 (low vigor) was observed at a temperature of $25{ }^{\circ} \mathrm{C}$, being higher than its activity at 15 and $35^{\circ} \mathrm{C}$. In general, the temperature of $15{ }^{\circ} \mathrm{C}$ in osmoprimed seeds provided lower APX activity than the others.

Osmopriming provided significant increases in peroxidase (POX) activity in the three analyzed lots, especially at $15^{\circ} \mathrm{C}$ (Figure 1D). The only exceptions were observed in Lot 1 (highest vigor) at $35^{\circ} \mathrm{C}$ and Lot 3 (low vigor) at $25^{\circ} \mathrm{C}$, with no differences in the activity of this enzyme. The highest POX activity was found at the temperature of $25^{\circ} \mathrm{C}$ compared to the others, mainly in Lots 1 (high vigor) and 2 (medium vigor). Lot 3 (low vigor) showed no difference in the POX activity of osmoprimed seeds between temperatures, while unprimed seeds presented the highest activity at the temperature of $25^{\circ} \mathrm{C}$.

Similar to CAT, the enzymes APX and POX are part of a wide group of peroxidase enzymes that act in the neutralization of $\mathrm{H}_{2} \mathrm{O}_{2}$ and several other physiological processes (De Gara, 2004). Therefore, these enzymes play key roles in neutralizing excess ROS at the cellular level (Kumar etal., 2015). In general and similar to what was observed in this study, osmopriming promoted significant increases in the activity of antioxidative enzymes (SOD, CAT, APX, and $\mathrm{POX}$ ) in crops such as sunflower (Bailly et al., 2000), rice (Hussain et al., 2016), sorghum (Zhang et al., 2015), maize (Ahmad et al., 2015), and wheat (Ali et al., 2017). The increase in the activity of these enzymes was attributed, in these studies, to the higher antioxidant protection of seeds, directly contributing to better physiological performance compared to unprimed seeds (Table 2).

Therefore, the results regarding the activity of antioxidant enzymes in Lots 2 (medium vigor) and 3 (low vigor) at the suband supra-optimal temperatures showed the role of osmopriming in the ability to tolerate the deleterious effects of oxidative stress caused by thermal stress. Despite causing deleterious effects, ROS are predominantly beneficial to cells when at baseline levels. In Hedysarum scoparium seeds, $\mathrm{H}_{2} \mathrm{O}_{2}$ is reported to promote seed germination subjected to low temperatures (Su, Lan, Pritchard, Xue, \& Wang, 2016). In tobacco seeds, $\mathrm{H}_{2} \mathrm{O}_{2}$ together with gibberellin is cited as essential in mobilizing reserves for the embryonic axis ( $\mathrm{Li}$ et al., 2018). Osmopriming associated with $\mathrm{H}_{2} \mathrm{O}_{2}$ and salicylic acid was essential in improving germination in maize seeds subjected to cold stress through various metabolic changes (Li 
et al., 2017). Therefore, the performance of antioxidative enzymes observed in this study shows an important role in neutralizing excess ROS, which characterizes oxidative stress (Mittler, 2017).

The principal component analysis (PCA) showed that the sum of components 1
(PC1) and 2 (PC2) of Lots 1 (high vigor) (Figure 2A), 2 (medium vigor) (Figure 2B), and 3 (low vigor) (Figure $2 \mathrm{C}$ ) were $83.8,87.1$, and $81.7 \%$, respectively. Therefore, PCA can be considered efficient regardless of the analyzed lots, as it explained more than $80 \%$ of the data variability (Jolliffe \& Cadima, 2016).
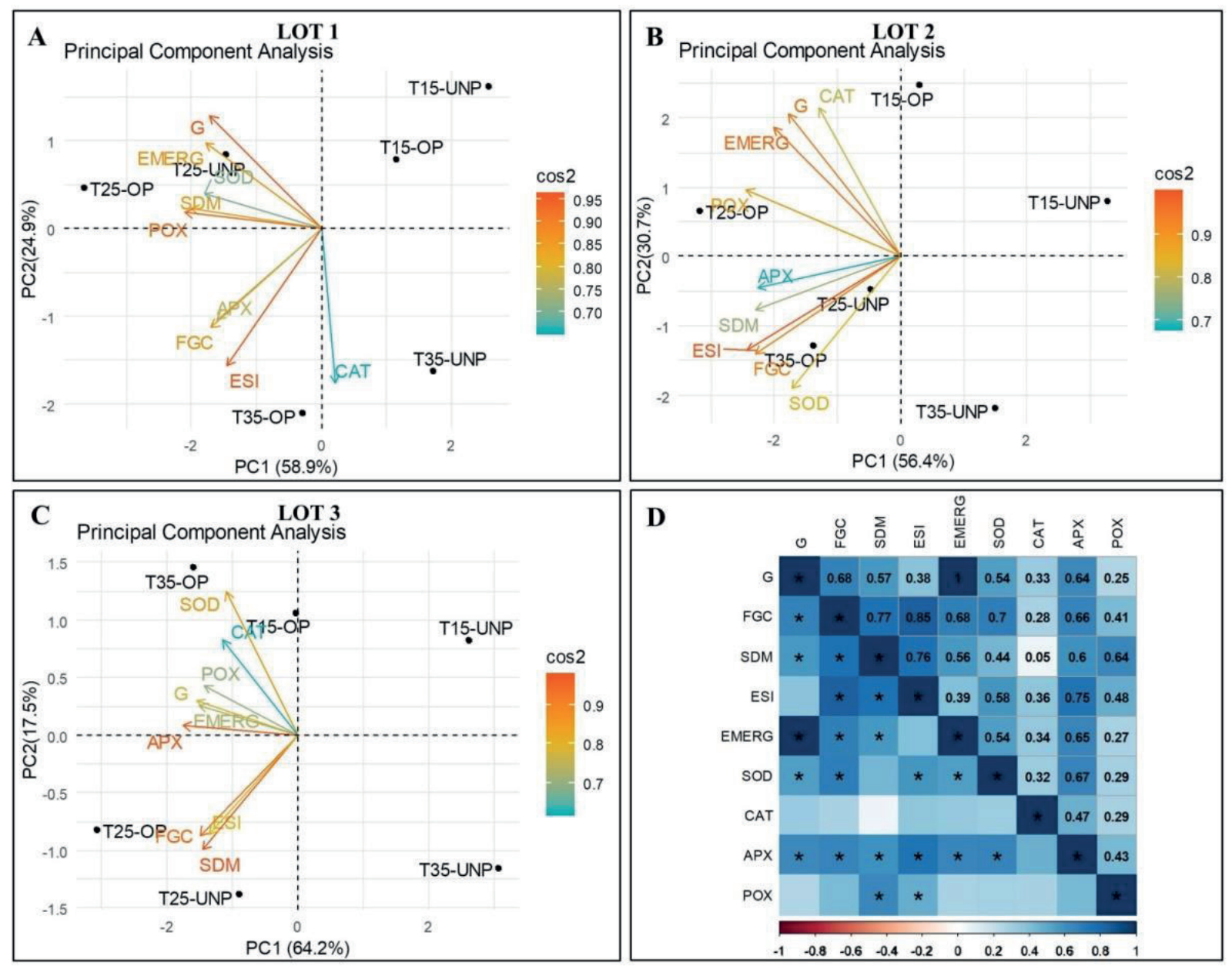

Figure 2. Biplot of the principal components analysis showing the first two components of the data obtained by the physiological quality tests and enzymatic analyses in three lots of sunflower seeds submitted to osmopriming and different temperatures ( $\mathrm{A}, \mathrm{B}$, and $\mathrm{C})$. Pearson linear correlation coefficients $(r)$ between physiologicaland biochemicalvariables. (D) Treatments:T15-UNP (unprimed seeds at $15^{\circ} \mathrm{C}$ ); T15-OP (osmoprimed seeds at $15^{\circ} \mathrm{C}$ ); T25-UNP (unprimed seeds at $25^{\circ} \mathrm{C}$ ); T25-OP (osmoprimed seeds at $25^{\circ} \mathrm{C}$ ); T35-UNP (unprimed seeds at $35^{\circ} \mathrm{C}$ ); T35-OP (osmoprimed seeds at $\left.35^{\circ} \mathrm{C}\right)$. Variables: Germination (G); First germination count (FGC); Seedling dry matter (SDM); Emergence speed index (ESI); Emergence (EMERG); Superoxide dismutase (SOD); Catalase (CAT); Ascorbate peroxidase (APX); Peroxidase (POX) (D). * = significant $(P \leq 0.05)$ by the t-test. 
The vectors of physiological quality (G, FGC, SDM, ESI, and EMERG) and antioxidative enzymes (SOD, CAT, APX, and POX) of the three analyzed lots were mainly concentrated in the negative scores of PC1, oppositely to the treatments of sub-optimal temperature (T15-OP and T15-UNP) and supra-optimal temperature without osmopriming (T35-UNP). On the other hand, there is clear proximity of these vectors to the treatments of optimal temperature (T25-OP and T25-UNP) and supra-optimal temperature with osmopriming (T35-OP). All of these results summarize those observed in the analysis of physiological and enzymatic tests, in which osmopriming assisted in improving the physiological quality of seeds, especially at optimal $\left(25^{\circ} \mathrm{C}\right)$ and supra-optimal temperatures $\left(35^{\circ} \mathrm{C}\right)$ in Lots 2 (medium vigor) and 3 (low vigor). Also, the higher susceptibility of seeds was evident when used at sub-optimal temperature $\left(15^{\circ} \mathrm{C}\right)$, regardless of the submission to osmopriming.

Pearson correlation analysis (Figure 2D) reinforced the results observed in PCA (Figure 2A, B, and C). Except for CAT and POX, most of the physiological (G, FGC, SDM, ESI, and EMERG) and biochemical (SOD, CAT, APX, and $P O X)$ variables were positively and significantly correlated with each other. It confirms that higher levels of germination and vigor in sunflower seeds are related to the activation of antioxidative enzymatic mechanisms, especially in osmoprimed sunflower seeds submitted to different temperatures.

\section{Conclusion}

The osmopriming of sunflower seeds with a PEG 6000 solution at $-2.0 \mathrm{MPa}$ for 8 hours is efficient to improve the performance of less vigorous lots under sub- and supraoptimal temperature conditions.
The higher tolerance of osmoprimed sunflower seeds to thermal stress is directly related to the higher activity of antioxidative enzymes.

\section{Acknowledgment}

The authors would like to thank the Conselho Nacional de Desenvolvimento Científico e Tecnológico (CNPq), the Coordenação de Aperfeiçoamento de Pessoal de Nível Superior (CAPES) (Financing Code 001), and the Fundação de Amparo à Pesquisa do Estado de Minas Gerais (FAPEMIG) for financial support.

\section{References}

Ahmad, I., Basra, S. M. A., Hussain, S., Hussain, S. A., Rehman, H., Rehman, A., \& Ali, A. (2015). Priming with ascorbic acid, salicylic acid and hydrogen peroxide improves seedling growth of spring maize at suboptimal temperature. Journal of Environmental and Agricultural Sciences, 3(18.6), 14-22.

Akladious, S. A. (2014). Influence of thiourea application on some physiological and molecular criteria of sunflower (Helianthus annuus L.) plants under conditions of heat stress. Protoplasma, 251(3), 625-638. doi: 10.1007/s00709-013-0563-2

Ali, Q., Daud, M. K., Haider, M. Z., Ali, S., Rizwan, M., Aslam, N.,... Zhu, S. J. (2017). Seed priming by sodium nitroprusside improves salt tolerance in wheat (Triticum aestivum L.) by enhancing physiological and biochemical parameters. Plant Physiology and Biochemistry, 119(2017), 50-58. doi: 10.1016/j.plaphy.2017.08.010 
Anderson, M. D., Prasad, T. K., \& Stewart, C. R. (1995). Changes in isozyme profiles of catalase, peroxidase, and glutathione reductase during acclimation to chilling in mesocotyls of maize seedlings. Plant Physiology, 109(4), 1247-1257. doi: 10.11 04/pp.109.4.1247

Araújo, S. D. S., Paparella, S., Dondi, D., Bentivoglio, A., Carbonera, D., \& Balestrazzi, A. (2016). Physical methods for seed invigoration: advantages and challenges in seed technology. Frontiers in Plant Science, 7, 646. doi: 10.3389/ fpls.2016.00646

Bailly, C., Benamar, A., Corbineau, F., \& Côme, D. (2000). Antioxidant systems in sunflower (Helianthus annuus L.) seeds as affected by priming. Seed Science Research, 10(1), 35-42. doi: 10.1017/S0960258500 000040

Balabusta, M., Szafrańska, K., \& Posmyk, M. M. (2016). Exogenous melatonin improves antioxidant defense in cucumber seeds (Cucumis sativus L.) germinated under chilling stress. Frontiers in Plant Science, 7(2016), 575. doi: 10.3389/fpls. 2016.00575

Beauchamp, C., \& Fridovich, I. (1971). Superoxide dismutase: improved assays and an assay applicable to acrylamide gels. Analytical Biochemistry, 44(1), 276287. doi: 10.1016/0003-2697(71)90370-8

Bewley, J. D., Bradford, K., \& Hilhorst, H. (2013). Seeds: physiology of development, germination and dormancy. New York: Springer Science \& Business Media.

Bradford, M. M. (1976). A rapid and sensitive method for the quantitation of microgram quantities of protein utilizing the principle of protein-dye binding. Analytical Biochemistry, 72(1-2), 248-254. doi: 10. 1016/ 0003-2697(76)90527-3

Chance, B., \& Maehly, A. C. (1955). Assay of catalase and peroxidases. Methods in Enzymology, 2(136), 764-775. doi: 10. 1016/S0076-6879(55)02300-8

Chojnowski, M., Corbineau, F., \& Côme, D. (1997). Physiological and biochemical changes induced in sunflower seeds by osmopriming and subsequent drying, storage and aging. Seed Science Research, 7(4), 323-332. doi: 10.1017/S0 $96025850000372 X$

Dai, L. Y., Zhu, H. D., Yin, K. D., Du, J. D., \& Zhang, Y. X. (2017). Seed priming mitigates the effects of saline-alkali stress in soybean seedlings. Chilean Journal of Agricultural Research, 77(2), 118-125. doi: 10.4067/ S0718-58392017000200118

Das, K., \& Roychoudhury, A. (2014). Reactive oxygen species (ROS) and response of antioxidants as ROS-scavengers during environmental stress in plants. Frontiers in Environmental Science, 2(2014), 53. doi: 10.3389/fenvs.2014.00053

De Bont, L., Naim, E., Arbelet-Bonnin, D., Xia, Q., Palm, E., Meimoun, P.,... Bouteau, F. (2019). Activation of plasma membrane $\mathrm{H}+$-ATPases participates in dormancy alleviation in sunflower seeds. Plant Science, 280(2019), 408-415. doi: 10.10 16/j.plantsci.2018.12.015

De Gara, L. (2004). Class III peroxidases and ascorbate metabolism in plants. Phytochemistry Reviews, 3(1-2), 195-205. doi: 10.1023/B:PHYT.0000047795.82713.99

Del Longo, O. T., González, C. A., Pastori, G. M., \& Trippi, V. S. (1993). Antioxidant defences 
under hyperoxygenic and hyperosmotic conditions in leaves of two lines of maize with differential sensitivity to drought. Plant and Cell Physiology, 34(7), 10231028. doi: 10.1093/oxfordjournals.pcp.a0 78515

Finch-Savage, W. E., \& Bassel, G. W. (2016). Seed vigour and crop establishment: extending performance beyond adaptation. Journal of Experimental Botany, 67(3), 567-591. doi: $10.1093 / j x b / e r v 490$

Giannopolitis, C. N., \& Ries, S. K. (1977). Superoxide dismutases: I. Occurrence in higher plants. Plant Physiology, 59(2), 309314. doi: 10.1104/pp.59.2.309

Gill, S. S., \& Tuteja, N. (2010). Reactive oxygen species and antioxidant machinery in abiotic stress tolerance in crop plants. Plant Physiology and Biochemistry, 48(12), 909-930. doi: 10.1016/j.plaphy.20 10.08.016

Górnik, K., \& Lahuta, L. B. (2017). Application of phytohormones during seed hydropriming and heat shock treatment on sunflower (Helianthus annuus L.) chilling resistance and changes in soluble carbohydrates. Acta Physiologiae Plantarum, 39(5), 118. doi: 10.1007/s11738-017-2413-x

Górnik, K., Badowiec, A., \& Weidner, S. (2014). The effect of seed conditioning, short-term heat shock and salicylic, jasmonic acid or brasinolide on sunflower (Helianthus annuus L.) chilling resistance and polysome formation. Acta Physiologiae Plantarum, 36(10), 2547-2554. doi: 10.10 07/s11738-0141626-5

Havir, E. A., \& McHale, N. A. (1987). Biochemical and developmental characterization of multiple forms of catalase in tobacco leaves. Plant Physiology, 84(2), 450-455. doi: 10.1104/pp.84.2.450

Henning, L., Ceronio, G., \& Nel, A. A. (2017). Emergence response of sunflower (Helianthus annuus) cultivars to supraoptimal soil temperatures. South African Journal of Plant and Soil, 34(3), 223-229. doi: 10.1080/02571862.2016.1266400

Hewezi, T., Léger, M., El Kayal, W., \& Gentzbittel, L. (2006). Transcriptional profiling of sunflower plants growing under low temperatures reveals an extensive downregulation of gene expression associated with chilling sensitivity. Journal of Experimental Botany, 57(12), 3109-3122. doi: 10.1093/jxb/erl080

Hussain, S., Khan, F., Hussain, H. A., \& Nie, L. (2016). Physiological and biochemical mechanisms of seed priming-induced chilling tolerance in rice cultivars. Frontiers in Plant Science, 7(2016), 116. doi: 10.33 89/fpls.2016.00116

Ibrahim, E. A. (2016). Seed priming to alleviate salinity stress in germinating seeds. Journal of Plant Physiology, 192(2016), 38-46. doi: 10.1016/j.jplph.2015.12.011

Jisha, K. C., Vijayakumari, K., \& Puthur, J. T. (2013). Seed priming for abiotic stress tolerance: an overview. Acta Physiologiae Plantarum, 35(5), 1381-1396. doi:10.1007/ s11738-012-1186-5

Jolliffe, I. T., \& Cadima, J. (2016). Principal component analysis: a review and recent developments. Philosophical Transactions of the Royal Society A: Mathematical, Physical and Engineering Sciences, 374(2065), 20150202. doi: 10.1098/rsta. 2015.0202 
Kar, M., \&Mishra, D. (1976). Catalase, peroxidase, and polyphenoloxidase activities during rice leaf senescence. Plant Physiology, 57(2), 315-319. doi: 10.1104/pp.57.2.315

Kononenko, G. P., Ustyuzhanina, M. I., \& Burkin, A. A. (2018). The problem of safe sunflower (Helianthus annuus L.) use for food and fodder purposes. Agricultural Biology, 53(3), 485-498. doi: 10.15389/ agrobiology.2018.3.485eng

Kumar, J. S. P., Prasad, S. R., Banerjee, R., \& Thammineni, C. (2015). Seed birth to death: dual functions of reactive oxygen species in seed physiology. Annals of Botany, 116(4), 663-668. doi: 10.1093/ aob/mcv 098

Li, Z., Gao, Y., Zhang, Y., Lin, C., Gong, D., Guan, Y., \& Hu, J. (2018). Reactive oxygen species and gibberellin acid mutual induction to regulate tobacco seed germination. Frontiers in Plant Science, 9(2016), 1279. doi: 10.3389/fpls.2018.01279

\section{Li, Z., Xu, J., Gao, Y., Wang, C., Guo, G., Luo, Y.,...} $\mathrm{Hu}, \mathrm{J}$. (2017). The synergistic priming effect of exogenous salicylic acid and $\mathrm{H} 2 \mathrm{O} 2$ on chilling tolerance enhancement during maize (Zea mays L.) seed germination. Frontiers in Plant Science, 8(2017), 1153. doi: 10.3389/fpls.2017.01153

Maguire, J. D. (1962). Speed of germination Aid in selection and evaluation for seedling emergence and vigor 1. Crop Science, 2(2), 176-177. doi: 10.2135/cropsci1962.0 011183X000200020033x

Michel, B. E., \& Kaufmann, M. R. (1973). The osmotic potential of polyethylene glycol 6000. Plant Physiology, 51(5), 914-916. doi: 10.1104/pp.51.5.914
Ministério da Agricultura, Pecuária e Abastecimento (2009). Regras para análise de sementes. Brasília: MAPA/ACS. Recuperado de http://www.agricultura. gov.br/assuntos/insumos-agropecuarios/ arquivos-publicacoes-insumos/2946_ regras_analise_sementes.pdf

Ministério da Agricultura, Pecuária e Abastecimento (2013). Padrões para produção e comercialização de sementes de girassol. Instrução Normativa no 45, de 17 de Setembro de 2013. Brasília. Recuperado de http://www.abrasem. com.br/wp-content/uploads/2012/10/ Instru\%C3\%A7\%C3\%A3o-Normativan\%C2\%BA-45-de-17-de-Setembrod e - 2013 - Padr\% C $3 \%$ B 5 e s - d e Identidade-e-Qualiidade-Prod-eComerc-de-Sementes-Grandes-Culturas-Republica\%C3\%A7\%C3\%A3oDOU-20.09.13.pdf

Mittler, R. (2017). ROS are good. Trends in Plant Science, 22(1), 11-19. doi: 10.1016/j. tplants.2016.08.002

Nakano,Y.,\&Asada,K.(1981).Hydrogenperoxide is scavenged by ascorbate-specific peroxidase in spinach chloroplasts. Plant and Cell Physiology, 22(5), 867-880. doi: 10.1093/oxfordjournals pcp.a07 6232

Noctor, G., Reichheld, J. P., \& Foyer, C. H. (2018). ROS-related redox regulation and signaling in plants. Seminars in Cell \& Developmental Biology, 80(2018), 3-12. doi: 10.1016/j.semcdb.2017.07.013

Pál, M., Gondor, O., \& Janda, T. (2013). Role of salicylic acid in acclimation to low temperature. Acta Agronomica Hungarica, 61(2), 161-172. doi: 10.1556/ AAgr.61.2013.2.7 
Paparella, S., Araújo, S. S., Rossi, G., Wijayasinghe, M., Carbonera, D., \& Balestrazzi, A. (2015). Seed priming: state of the art and new perspectives. Plant Cell Reports, 34(8), 1281-1293. doi: 10.1007/ s002 99-015-1784-y

Peixoto, P. H. P., Cambraia, J., Sant'Anna, R. Mosquim, P. R., \& Moreira, M. A. (1999). Aluminum effects on lipid peroxidation and on the activities of enzymes of oxidative metabolism in sorghum. Revista Brasileira de Fisiologia Vegetal, 11(3), 137-143.

R Core Team (2018). R: A language and environment for statistical computing. Vienna: $\mathrm{R}$ Foundation for Statistical Computing. Retrieved from http://www.Rproject.org/

Rondanini, D. P., Savin, R., \& Hall, A. J. (2007). Estimation of physiological maturity in sunflower as a function of fruit water concentration. European Journal of Agronomy, 26(3), 295-309. doi: 10.1016/j. eja.2006.11.001

Seiler, G. J., Qi, L. L., \& Marek, L. F. (2017). Utilization of sunflower crop wild relatives for cultivated sunflower improvement. Crop Science, 57(3), 1083-1101. doi: 10.2135/cropsci2016.10.0856

Singh, N. B., Singh, D., \& Singh, A. (2015). Biological seed priming mitigates the effects of water stress in sunflower seedlings. Physiology and Molecular Biology of Plants, 21(2), 207-214. doi: $10.1007 / s 12298-015-0291-5$
Su, L., Lan, Q., Pritchard, H. W., Xue, H., \& Wang, X. (2016). Reactive oxygen species induced by cold stratification promote germination of Hedysarum scoparium seeds. Plant Physiology and Biochemistry, 109(2016), 406-415. doi: 10.1016/j. plaphy.2016.10.025

Wang, Y., Cui, Y., Hu, G., Wang, X., Chen, H., Shi, Q.... Zhang, Y. (2018). Reduced bioactive gibberellin content in rice seeds under low temperature leads to decreased sugar consumption and low seed germination rates. Plant physiology and Biochemistry, 133(2018), 1-10. doi: 10.1016/j.plaphy.20 18.10. 020

Ye, N., Zhu, G., Liu, Y., Zhang, A., Li, Y., Liu, R.,... Zhang, J. (2012). Ascorbic acid and reactive oxygen species are involved in the inhibition of seed germination by abscisic acid in rice seeds. Journal of Experimental Botany, 63(5), 1809-1822. doi: 10.1093/ jxb/err336

Zhang, F., Yu, J., Johnston, C. R., Wang, Y., Zhu, K., Lu, F.,... Zou, J. (2015). Seed priming with polyethylene glycol induces physiological changes in sorghum (Sorghum bicolor L. Moench) seedlings under suboptimal soil moisture environments. PLoS One, 10(10). doi: 10.1371/journal.pone.0140620 
